\title{
Diversity of Cropping Patterns and Land Use Practices in Faridpur Region
}

\author{
A B M Mostafizur ${ }^{*}$, M A U Zaman ${ }^{1}$, S M Shahidullah ${ }^{1}$ and M Nasim ${ }^{1}$
}

\begin{abstract}
The development of agriculture sector largely depends on the reliable and comprehensive statistics of the existing cropping patterns, cropping intensity and crop diversity of a particular area, which will provide guideline to policy makers, researchers, extensionists and development workers. The study was conducted over all 29 upazilas of Faridpur region during 2015-16 using pre-tested semi-structured questionnaire with a view to document the existing cropping patterns, cropping intensity and crop diversity of this area. From the present study it was observed that about $43.23 \%$ net cropped area (NCA) was covered by only jute based cropping patterns on the other hand deep water ecosystem occupied about $36.72 \%$ of the regional NCA. The most dominant cropping pattern Boro-FallowFallow occupied about $24.40 \%$ of NCA with its distribution over 28 out of 29 . The second largest area, $6.94 \%$ of NCA, was covered by Boro-B. Aman cropping pattern, which was spread out over 23 upazilas. In total 141 cropping patterns were identified under this investigation. The highest number of cropping patterns was identified 44 in Faridpur sadar and the lowest was 12 in Kashiani of Gopalganj and Pangsa of Rajbari. The lowest crop diversity index (CDI) was reported 0.448 in Kotalipara followed by 0.606 in Tungipara of Gopalganj. The highest value of CDI was observed 0.981 in Faridpur sadar followed by 0.977 in Madhukhali of Faridpur. The range of cropping intensity value was recorded 113$262 \%$. The maximum value was for Saltha of Faridpur and minimum for Kotalipara of Gopalganj. As a whole the CDI of Faridpur region was calculated 0.971 and the average cropping intensity at regional level was $197 \%$.
\end{abstract}

Key words: Cropping system, jute, diversity index and deep-water ecosystem

\section{INTRODUCTION}

The term cropping system refers to the crops, cropping patterns and the management techniques used on a particular field over the period of a year. This term is not a new one, but it has been used more often in recent years in discussions about sustainability of our agricultural production systems. Cropping pattern is the yearly sequence and spatial arrangement of crops or of crops and fallow on a given area (Chandrasekaran et al., 2010). The cropping patterns of a region are closely influenced by the geo-climatic, socio-economic, historical and political factors (Hussain, 1996). It also depends on topography, slope, soils and availability of water for irrigation, use of pesticides, fertilizers and mechanization.
Weather plays a decisive role in determining the existing cropping pattern. Faridpur region is a low lying area of the country.

Faridpur municipality was established in 1869, which is divided into five districts in modern days. These are Faridpur, Rajbari, Gopalganj, Madaripur and Shariatpur. Collectively all these districts are known as Faridpur region. It is mostly a riverine area of the country belongs to Active Ganges River Floodplain (AEZ-10), Low Ganges River Floodplain (AEZ-12), Gopalganj-Khulna Bils (AEZ-14) and Old Meghna Estuarine Floodplain (AEZ-19) (FAO, 1988). Most of the soils of this region are floodplain and basin type, which are formed from the river deposits. Sedimentation occurs in every year in this region due to the regular flooding. As a result soils of this region

${ }^{1}$ Rice Farming Systems Division, BRRI, Gazipur; *Corresponding author's E-mail: abmm.brri@gmail.com 
are very fertile and diversified crops can be grown there during the rainy season as well as in winter. This region is well known for jute and rice cultivation. Several adverse situations e.g. deep flood, flash flood, peat soils, heavy basin clays, noxious perennial weeds, slow drainage affect the cultivation of different crops. As a result the cropping intensity in this region is much lower than the other region like Bogra, Dinajpur, Jessore. Diversified cropping pattern may be an option for the farmers as a coping strategy against risks (Mandal and Bezbaruah, 2013). Typology of different cropping systems is the base for the managers of these systems to intensify production (Shriar, 2000). There is a strong need for judicious and appropriate use limited resources in case of intervention selection that does not lead to increased mal adaption or inequity in the society over long term. Existing trends of available agricultural lands is most essential requirement for any land use planning related to farming and food security in a sustainable manner. Therefore, an increased understanding of arable land use based on the cropping system is essential for the appropriate intervention in sustainable way. In these contexts, existing cropping patterns along with their diversity of such complex agricultural region are very crucial for risk minimization and overall productivity improvement. The present study was designed with the following specific objectives to:

- Understand the existing cropping patterns scenario in Faridpur region

- Visualize the existing land use pattern at upazila and regional level

- Determine the crop diversity and cropping intensity at local and regional level.

\section{METHODOLOGY}

Twenty-nine upazilas of Faridpur, Goplaganj, Shariatpur, Madaripur and Rajbari districts under Faridpur agricultural region were the locale of this study. Data were collected using double stage procedure. At initial stage, data were collected through pre-tested semi-structured questionnaire from 29 preassigned Sub-Assistant Agriculture Officers (SAAO) of each upazila during July 2015 at upazila level. SAAOs were purposively preselected by Agriculture Extension Officers (AEO), Additional Agriculture Officer (AAO) and upazila Agriculture Officer (UAO) or altogether. Prior to data collection, the pretested questionnaire was explained along with proper guidelines to the AEOs or UAOs or both and handed over to them at each Deputy Director's office of Department of Agricultural Extension (DAE) during monthly meeting for the sake of accurate data collection. The filled questionnaires were collected by the scientists of RFS Division, checked, and analyzed to find the inconsistencies of the supplied data before validation workshop. All the inconsistencies among the information were documented. The collected data along with documented inconsistencies were discussed in district level workshop for necessary correction and validation. Second stage of data collection was based on day-long data validation workshop at district level. The workshop dates were 18 August 2015 for Rajbari; 30 May 2016 for Faridpur; 31 May 2016 for Shariatpur; 25 July 2016 for Gopalganj and 26 July 2016 for Madaripur. Four field-workers i.e. one SAPPO and three SAAOs experienced and engaged in crop-based data documentation, all officers from all upazilas viz UAOs, AEOs, AAEOs, DD (DAE), DD (Horticulture), DD of Seed Certification Agency, DTO and ADDs, one representative from Agricultural Training Institute (ATI) and scientists of BRRI regional station, Bhanga and Kushtia participated in the data validation workshop. The number of participants of validation workshop ranged from 40 to 69 in each district. All the participants were divided into three to four groups for data validation. Each group was facilitated by two RFSD scientists to finalize and validate the data and authenticated data were captured. Crop diversity index was calculated by using the following equation described by Kshirsagar et al. (1997). 


$$
C D I_{i}=1-\sum_{j=o}^{n}\left(\frac{a_{i j}}{A_{i}}\right)^{2}
$$

Where, $\mathrm{CDI}_{\mathrm{i}}=$ Crop Diversity Index

$a_{i j}=$ Area planted to the $j^{\text {th }}$ crop in the $i^{\text {th }}$ location

$A_{i}=$ Total area planted under all crops

The index is zero for a land area growing only one crop. It approaches unity as the level of diversity increases. Compilation and processing of the collected data were done using Microsoft Excel programme. Descriptive statistics were used to facilitate the presentation of the findings.

\section{RESULTS AND DISCUSSION}

\section{Land use}

Table 1 presents the status of agricultural land utilization. The net cropped area of the Faridpur region is 490,490 hectares. Crops occupied the particular land for round the year were considered under annual crops. The major annual crops reported in the region were pineapple, sugarcane, banana papaya, betel leaf, ginger and turmeric. The annual crops area in different upazilas ranged from 10 to 2,000 ha. The annual crops area accounted only $2.45 \%$ of the net cropped area (NCA) in the region. At a glance the region possesses $25 \%$ single cropped area (SCA), $47 \%$ double cropped area (DCA), $24.6 \%$ triple cropped area (TCA). The quadruple cropped area is absent in this region. The SCA had the major share of NCA in Kotalipara, and Tungipara upazilas of Gopalganj district; Kalkini upazila of Madaripur district; Damudya and Naria upazilas of Shariatpur district followed by corresponding double cropped area (DCA). Most of the upazilas were dominated by DCA. The exceptions are Madhukhali and Saltha of Faridpur district and Baliakandi, Kalukhali, Pangsa and Rajbari sadar of Rajbari district where triple cropped area is the dominating one (Table 1). The area which could not be defined under SCA, DCA, TCA or QCA, was considered as others whose coverage is less than $1 \%$ of the NCA.

\section{Cropping patterns of Faridpur}

In total 141 cropping patterns were observed in Faridpur region of which six cropping patterns with exclusive rice crop covers over $35 \%$ of the NCA. There were 46 cropping patterns with exclusive non-rice crop covering over $28 \%$ of the NCA. Rest of the NCA i.e. about $37 \%$ area is covered by 89 rice-non rice cropping patterns (Appendix 1).

\section{Rice and non-rice crops at a glance}

Table 2 presents six cropping patterns where rice is the only crop round the year. It comprises about $35.23 \%$ of the NCA in the region. Among them single rice, double rice and triple rice areas represent around $24.44 \%, 10.69 \%$ and $0.03 \%$ respectively. It reflects the unparallel dominance of rice in the cropping systems in Faridpur region. In case of individual pattern Boro-Fallow-Fallow has the highest coverage $(24.41 \%)$ and was recorded in 28 upazilas out of 29. The second dominant cropping pattern Boro- B. Aman occupied $6.94 \%$ of NCA which was reported in 23 upazilas. Boro-Fallow- T. Aman covered $3.6 \%$ area with its existence in 22 upazilas.

In the current investigation, 46 cropping patterns were identified that was free from rice. Among the 46 patterns, first 32 have been arranged in descending order (Table 3). The rest 14 patterns with negligible area coverage (Table 8) were arranged with other patterns of different categories. Aggregate of the 46 patterns have had $28.45 \%$ of NCA. In critical comparison it is clear that exclusive rice area is more or less same as exclusive non-rice area. In Faridpur region crop diversity is much wider than that of other regions like Sylhet and Chittagong where exclusive rice area covers 37 folds and 23 folds respectively, of exclusive non-rice area (Muttaleb et al., 2017; Shahidullah et al., 2017). Appropriate cropping patterns may facilitate maximum possible land use as well as efficient use of other scarce resources in a sustainable manner. Diversified cropping pattern may be an option for the farmers as a coping strategy against risks (Mandal and Bezbaruah, 2013). Typology of different cropping systems is 
Table 1. Land use of different upazilas in Faridpur region (area in hectare), 2014-15.

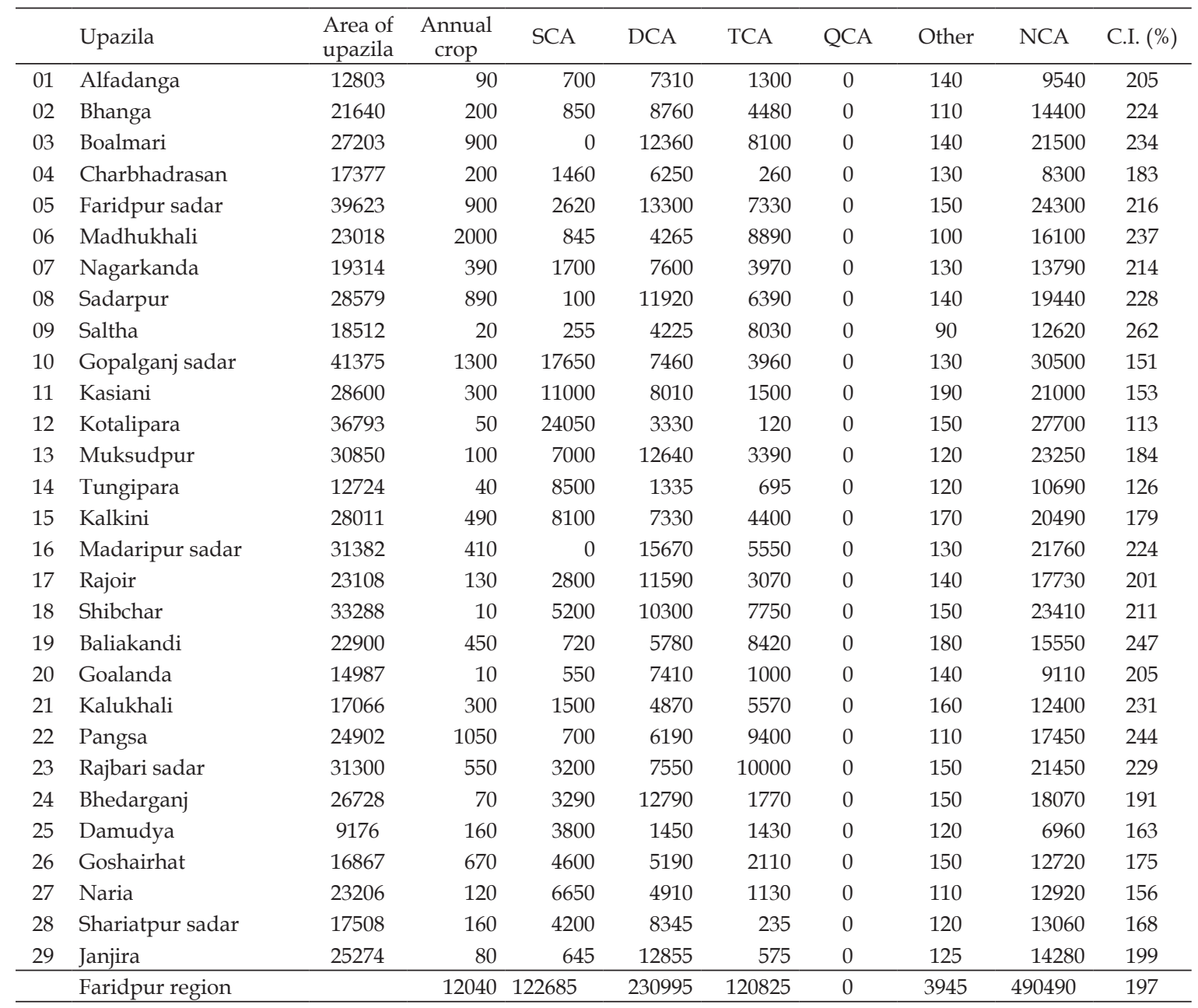

the base for the managers of these systems to intensify production (Shriar, 2000). Light textured soil with low-water holding capacity are discouraging factors for modern rice cultivation specially in dry season. Moreover, supply of modern varieties of various crops, knowledge of modern crop management practices, good communication facilities, skilled technology transfer channel help crop diversification in a given area $(\mathrm{FAO}, 1988)$.

\section{Pulse crops}

Thirty-eight cropping patterns are holding different pulse crops (Table 4). Among them lentil is covering the largest area whereas mungbean is cultivated in the smallest area.
The cropping patterns of only lentil altogether cover more than one-half of pulse growing area in the region. Grasspea holds the second position in pulse crop cultivation in Faridpur region. There are 11 cropping patterns for grasspea, which occupy over $2 \%$ of NCA. In the documentation of pulse cropping, LentilJute-Fallow reported its widest spreading over 22 upazilas in the region. The aggregate area of the pulse cropping systems stands for $14.68 \%$ of the NCA in Faridpur region.

\section{Spices crops}

Spices crops play an important role in the economy of Faridpur region. Twenty-seven cropping patterns are holding different spices 
Table 2. Cropping patterns with exclusive rice in Faridpur region, 2014-15.

\begin{tabular}{llrrr}
\hline & Cropping pattern & Area (ha) & \% of NCA & Frequency (no. of upazila) \\
\hline 01 & Boro-Fallow-Fallow & 119750 & 24.41 & 28 \\
02 & Boro-B. Aman & 34060 & 6.94 & 23 \\
03 & Boro-Fallow-T. Aman & 17685 & 3.61 & 22 \\
04 & Boro-Aus-Fallow & 685 & 0.14 & 6 \\
05 & Fallow-B. Aman & 500 & 0.10 & 1 \\
06 & Boro-Aus-T. Aman & 150 & 0.03 & 2 \\
\hline
\end{tabular}

Table 3. Cropping patterns with exclusive non-rice in Faridpur region, 2014-15.

\begin{tabular}{|c|c|c|c|c|}
\hline & Cropping pattern & Area (ha) & $\%$ of NCA & Frequency (no. of upazila) \\
\hline 01 & Onion-Jute-Fallow & 25960 & 5.29 & 23 \\
\hline 02 & Wheat-Jute-Fallow & 23210 & 4.73 & 25 \\
\hline 03 & Lentil-Jute-Fallow & 15330 & 3.12 & 22 \\
\hline 04 & Mustard-Jute-Fallow & 13880 & 2.83 & 18 \\
\hline 05 & Grasspea-Jute-Fallow & 12680 & 2.58 & 18 \\
\hline 06 & Vegetab-Vegetab-Vegetab & 8420 & 1.72 & 16 \\
\hline 07 & Coriander-Jute-Fallow & 6510 & 1.33 & 12 \\
\hline 08 & Garlic-Jute-Fallow & 6020 & 1.23 & 16 \\
\hline 09 & Vegetab-Vegetab-Fallow & 4255 & 0.87 & 13 \\
\hline 10 & Vegetab-Jute-Fallow & 3820 & 0.78 & 6 \\
\hline 11 & Chilli-Jute-Fallow & 2045 & 0.42 & 9 \\
\hline 12 & Lentil-Vegetab-Vegetab & 1910 & 0.39 & 2 \\
\hline 13 & Blackcumin-Jute-Fallow & 1780 & 0.36 & 10 \\
\hline 14 & Potato-Jute-Fallow & 1735 & 0.35 & 10 \\
\hline 15 & Groundnut-Fallow-Fallow & 1480 & 0.30 & 4 \\
\hline 16 & Chilli-Fallow-Fallow & 1360 & 0.28 & 5 \\
\hline 17 & Lentil-Sesame-Fallow & 1125 & 0.23 & 5 \\
\hline 18 & Pea-Jute-Fallow & 910 & 0.19 & 8 \\
\hline 19 & Chilli-Vegetab-Fallow & 810 & 0.17 & 6 \\
\hline 20 & Blackgram-Jute-Fallow & 735 & 0.15 & 6 \\
\hline 21 & Sesame-Fallow-Blackgram & 680 & 0.14 & 4 \\
\hline 22 & W.Melon-Fallow-Fallow & 510 & 0.10 & 2 \\
\hline 23 & Groundnut-Fallow-Blackgram & 500 & 0.10 & 1 \\
\hline 24 & Onion-Sesame-Fallow & 500 & 0.10 & 3 \\
\hline 25 & S.Potato-Fallow-Fallow & 495 & 0.10 & 5 \\
\hline 26 & Vegetab-Fallow-Fallow & 450 & 0.09 & 3 \\
\hline 27 & Onion-Vegtab-Vegetab & 400 & 0.08 & 1 \\
\hline 28 & Fallow-Fallow-Blackgram & 370 & 0.08 & 4 \\
\hline 29 & Wheat-Ginger/Turmeric & 350 & 0.07 & 1 \\
\hline 30 & S.Potato-Jute-Fallow & 230 & 0.05 & 4 \\
\hline 31 & Wheat-Sesame-Fallow & 230 & 0.05 & 2 \\
\hline 32 & Grasspea-Sesame-Fallow & 210 & 0.04 & 2 \\
\hline \multirow[t]{2}{*}{$33-46$} & Other 14 patterns (in Table 8) & 740 & 0.15 & \\
\hline & Total & 139640 & 28.45 & \\
\hline
\end{tabular}


Table 4. Area covered by pulse crops under cropping system in Faridpur region, 2014-15.

\begin{tabular}{|c|c|c|c|c|}
\hline & Cropping pattern & Area (ha) & $\%$ of NCA & Frequency (no. of upazila) \\
\hline 01 & Lentil-Jute-Fallow & 15330 & 3.13 & 22 \\
\hline 02 & Lentil-Jute-T. Aman & 13230 & 2.70 & 21 \\
\hline 03 & Grasspea-Jute-Fallow & 12680 & 2.59 & 18 \\
\hline 04 & Grasspea-B. Aman & 4140 & 0.84 & 9 \\
\hline 05 & Lentil-Sesame-T. Aman & 3280 & 0.67 & 5 \\
\hline 06 & Grasspea-Jute-T. Aman & 2460 & 0.50 & 11 \\
\hline 07 & Lentil-B. Aman & 2130 & 0.43 & 7 \\
\hline 08 & Lentil-Vegetab-Vegetab & 1910 & 0.39 & 2 \\
\hline 09 & Pea-B. Aman & 1730 & 0.35 & 4 \\
\hline 10 & Grasspea-Fallow-T. Aman & 1510 & 0.31 & 2 \\
\hline 11 & Grasspea-Boro-Fallow & 1430 & 0.29 & 2 \\
\hline 12 & Blackgram-B. Aman & 1300 & 0.27 & 4 \\
\hline 13 & Boro-Fallow-Blackgram & 1250 & 0.25 & 4 \\
\hline 14 & Lentil-Sesame-Fallow & 1125 & 0.23 & 5 \\
\hline 15 & Pea-Jute-Fallow & 910 & 0.19 & 8 \\
\hline 16 & Lentil-Fallow-T. Aman & 830 & 0.17 & 2 \\
\hline 17 & Grasspea-B.Aus+B. Aman & 770 & 0.16 & 3 \\
\hline 18 & Blackgram-Jute-Fallow & 735 & 0.15 & 6 \\
\hline 19 & Grasspea-Sesame-T. Aman & 700 & 0.14 & 1 \\
\hline 20 & Sesame-Fallow-Blackgram & 680 & 0.14 & 4 \\
\hline 21 & Lentil-Aus-Fallow & 670 & 0.14 & 4 \\
\hline 22 & Wheat-Aus-Blackgram & 550 & 0.11 & 1 \\
\hline 23 & Groundnut-Fallow-Blackgram & 500 & 0.10 & 1 \\
\hline 24 & Fallow-Fallow-Blackgram & 370 & 0.08 & 4 \\
\hline 25 & Lentil-Aus-T. Aman & 350 & 0.07 & 2 \\
\hline 26 & Grasspea-Aus-T. Aman & 330 & 0.07 & 1 \\
\hline 27 & Pea-Fallow-T. Aman & 290 & 0.06 & 3 \\
\hline 28 & Grasspea-Sesame-Fallow & 210 & 0.04 & 2 \\
\hline 29-38 & Other 10 patterns (in Table 8) & 585 & 0.12 & \\
\hline & Total pulse crops & 71985 & 14.68 & \\
\hline
\end{tabular}

crops (Table 5). Among them onion alone is leading nine cropping patterns covering the largest area of 56,450 hectares which is equivalent to $11.50 \%$ of $\mathrm{NCA}$ in the region. Garlic holds the second position in spices crops leading five cropping patterns covering 13,210 hectares (2.69\% of NCA). Blackcumin is a special crop with multidimensional uses. For its medicinal use it is a high value commodity in the market. Faridpur agricultural region is specially famous for the production of blackcumin. This crop is leading two patterns covering 3,000 hectares. Light textured soil and siltation by flood water are encouraging factors for spices. Moreover, extensive jute cultivation enriches soil organic matter, makes the soil friable and free from weed. All the aforesaid determinants along with marketing facilities are helping spices crop production. Favourable climate, supply of modern varieties, knowledge of modern crop management practices, good communication facilities, skilled technology transfer channel help extensive production of demanded crop (FAO, 1988).

\section{Fibre crops}

Socially and economically jute is an important crop in the Faridpur region. Thirty-six cropping patterns were identified based on jute (Table 6). It is observed that the jute based cropping patterns covered $43.49 \%$ of NCA of the Faridpur region. Among them WheatJute-T. Aman cropping pattern alone occupied 
Table 5. Cropping patterns with spices crops in Faridpur region, 2014-15.

\begin{tabular}{|c|c|c|c|c|}
\hline & Cropping pattern & Area (ha) & $\%$ of NCA & Frequency (no. of upazila) \\
\hline 01 & Onion-Jute-Fallow & 25960 & 5.29 & 23 \\
\hline 02 & Onion-Jute-T. Aman & 24510 & 4.99 & 14 \\
\hline 03 & Coriander-Jute-Fallow & 6510 & 1.33 & 12 \\
\hline 04 & Garlic-Jute-Fallow & 6020 & 1.23 & 16 \\
\hline 05 & Chilli-B. Aman & 4370 & 0.89 & 6 \\
\hline 06 & Garlic-Jute-T. Aman & 3570 & 0.73 & 8 \\
\hline 07 & Coriander-Jute-T. Aman & 3380 & 0.69 & 11 \\
\hline 08 & Onion-Aus-Fallow & 2860 & 0.58 & 5 \\
\hline 09 & Chilli-Jute-Fallow & 2045 & 0.42 & 9 \\
\hline 10 & Blackcumin-Jute-Fallow & 1780 & 0.36 & 10 \\
\hline 11 & Onion-B. Aman & 1620 & 0.33 & 5 \\
\hline 12 & Chilli-Aus-Fallow & 1570 & 0.32 & 3 \\
\hline 13 & Chilli-Fallow-Fallow & 1360 & 0.28 & 5 \\
\hline 14 & Blackcumin-Jute-T. Aman & 1220 & 0.25 & 9 \\
\hline 15 & Chilli-Vegetab-Fallow & 810 & 0.17 & 6 \\
\hline 16 & Coriander-Sesame-T. Aman & 700 & 0.14 & 1 \\
\hline 17 & Chilli-Fallow-T. Aman & 620 & 0.13 & 3 \\
\hline 18 & Onion-Sesame-Fallow & 500 & 0.10 & 3 \\
\hline 19 & Garlic-B. Aman & 480 & 0.10 & 3 \\
\hline 20 & Onion-Vegtab-Vegetab & 400 & 0.08 & 1 \\
\hline 21 & Onion-Sesame+B. Aman & 300 & 0.06 & 1 \\
\hline 22 & Garlic-Aus-Fallow & 280 & 0.06 & 3 \\
\hline \multirow[t]{2}{*}{$23-27$} & Other five patterns (in Table 8) & 490 & 0.10 & - \\
\hline & Total spices crops & 58305 & 11.89 & \\
\hline
\end{tabular}

$6.74 \%$ of the NCA which is distributed over 26 upazilas out of 29 covering 33,045 hectares of land area. The second prevailing Onion-JuteFallow covers about 25,960 hectare area which is $5.29 \%$ of the NCA. Wheat-Jute-Fallow stands in fourth position in terms of area coverage but it is widely distributed over 25 upazilas out of 29 which is the second highest position in respect to distribution of the pattern in the region. Well-drained light-textured soil makes the friendly situation for early growth stages of jute. High temperature, high humidity and satisfactory rainfall are the pre-requisites for cultivation of the crop. Plenty of flood water is on time available in the region for jute retting. Clear sun-shine during the harvesting period is an extra facility for post-harvest management of fibre and stick. Now-a-days jute-stick also has a good market value with export potential. All these make a favourable package, which encourages the farmers for extensive jute cultivation in the region (FAO, 1988).

\section{Deep-water rice ecosystem}

Deep water is a special type of ecosystem in the country. In context of Faridpur region this ecosystem is very important. Table 7 presents the cropping patterns under deep water ecosystem. Among the listed 25 patterns Boro-B. Aman cropping pattern covers the highest area of 34,060 hectares which represents $6.94 \%$ of the region's NCA. This pattern is distributed over 23 upazilas out of 29. The second highest Chilli-B. Aman cropping pattern covers 4,370 hectares and distributed over six upazilas. In total the area allocated for deep water rice cultivation is 61,725 hectares, which is equivalent to $12.58 \%$ of NCA in Faridpur region. The water level of this ecosystem ranges between 150 and 400 $\mathrm{cm}$, and water usually remains 3-4 months. Special rice varieties known as 'floating rice' are planted in these areas. In the past Bangladesh had a land coverage of three million hectares for deepwater rice (Jackson et al., 1972). In course of time the continuous effort on modern agriculture shifted DWR area mainly to modern 
Table 6. Cropping patterns with jute crops in Faridpur region, 2014-15.

\begin{tabular}{|c|c|c|c|c|}
\hline & Cropping pattern & Area (ha) & $\%$ of NCA & Frequency (no. of upazila) \\
\hline 01 & Wheat-Jute-T. Aman & 33045 & 6.74 & 26 \\
\hline 02 & Onion-Jute-Fallow & 25960 & 5.29 & 23 \\
\hline 03 & Onion-Jute-T. Aman & 24510 & 5.00 & 14 \\
\hline 04 & Wheat-Jute-Fallow & 23210 & 4.73 & 25 \\
\hline 05 & Lentil-Jute-Fallow & 15330 & 3.13 & 22 \\
\hline 06 & Mustard-Jute-Fallow & 13880 & 2.83 & 18 \\
\hline 07 & Lentil-Jute-T. Aman & 13230 & 2.70 & 21 \\
\hline 08 & Grasspea-Jute-Fallow & 12680 & 2.59 & 18 \\
\hline 09 & Mustard-Jute-T. Aman & 10580 & 2.16 & 17 \\
\hline 10 & Coriander-Jute-Fallow & 6510 & 1.33 & 12 \\
\hline 11 & Garlic-Jute-Fallow & 6020 & 1.23 & 16 \\
\hline 12 & Vegetab-Jute-Fallow & 3820 & 0.78 & 6 \\
\hline 13 & Garlic-Jute-T. Aman & 3570 & 0.73 & 8 \\
\hline 14 & Coriander-Jute-T. Aman & 3380 & 0.69 & 11 \\
\hline 15 & Grasspea-Jute-T. Aman & 2460 & 0.50 & 11 \\
\hline 16 & Vegetab-Jute-T. Aman & 2290 & 0.47 & 6 \\
\hline 17 & Chilli-Jute-Fallow & 2045 & 0.42 & 9 \\
\hline 18 & Blackcumin-Jute-Fallow & 1780 & 0.36 & 10 \\
\hline 19 & Potato-Jute-Fallow & 1735 & 0.35 & 10 \\
\hline 20 & Blackcumin-Jute-T. Aman & 1220 & 0.25 & 9 \\
\hline 21 & Fallow-Jute-T. Aman & 1200 & 0.24 & 1 \\
\hline 22 & Boro-Jute-Fallow & 1150 & 0.23 & 3 \\
\hline 23 & Pea-Jute-Fallow & 910 & 0.19 & 8 \\
\hline 24 & Blackgram-Jute-Fallow & 735 & 0.15 & 6 \\
\hline 25 & Potato-Jute-T. Aman & 485 & 0.10 & 7 \\
\hline 26 & Boro-Jute-T. Aman & 400 & 0.08 & 1 \\
\hline 27 & Sesame-Jute-T. Aman & 260 & 0.05 & 1 \\
\hline 28 & S.Potato-Jute-Fallow & 230 & 0.05 & 4 \\
\hline \multirow[t]{2}{*}{$29-36$} & Other eight patterns (in Table 8) & 710 & 0.14 & \\
\hline & Total area for jute & 213335 & 43.49 & \\
\hline
\end{tabular}

Table 7. Cropping patterns under deep water rice ecosystem in Faridpur region, 2014-15.

\begin{tabular}{|c|c|c|c|c|}
\hline & Cropping pattern & Area (ha) & $\%$ of NCA & Frequency (no. of upazila) \\
\hline 01 & Boro-B. Aman & 34060 & 6.94 & 23 \\
\hline 02 & Chilli-B. Aman & 4370 & 0.89 & 6 \\
\hline 03 & Grasspea-B. Aman & 4140 & 0.84 & 9 \\
\hline 04 & Mustard-Boro-B. Aman & 2620 & 0.53 & 2 \\
\hline 05 & Groundnut-B. Aman & 2400 & 0.49 & 3 \\
\hline 06 & Lentil-B. Aman & 2130 & 0.43 & 7 \\
\hline 07 & Pea-B. Aman & 1730 & 0.35 & 4 \\
\hline 08 & Onion-B. Aman & 1620 & 0.33 & 5 \\
\hline 09 & Wheat-B. Aman & 1500 & 0.31 & 5 \\
\hline 10 & Blackgram-B. Aman & 1300 & 0.27 & 4 \\
\hline 11 & Mustard-B. Aman & 990 & 0.20 & 3 \\
\hline 12 & Mustard-B.Aus+B. Aman & 980 & 0.20 & 3 \\
\hline 13 & Grasspea-B.Aus+B. Aman & 770 & 0.16 & 3 \\
\hline 14 & W.Melon-B. Aman & 505 & 0.10 & 2 \\
\hline 15 & Fallow-B. Aman & 500 & 0.10 & 1 \\
\hline 16 & Garlic-B. Aman & 480 & 0.10 & 3 \\
\hline 17 & Vegetab-B. Aman & 430 & 0.09 & 2 \\
\hline 18 & Mustard-Sesame+B. Aman & 350 & 0.07 & 1 \\
\hline 19 & Onion-Sesame+B. Aman & 300 & 0.06 & 1 \\
\hline $20-25$ & Other six patterns (in Table 8) & 550 & 0.11 & \\
\hline & Total deep-water rice area & 61725 & 12.58 & \\
\hline
\end{tabular}


Boro. Now the area under deep water rice in Bangladesh is reduced to 0.4 million hectares (Nasim et al., 2017). Though this cropping system is less productive than other modern cropping systems, however, the specific fragile ecosystem still struggling because of no other alternatives.

\section{Sporadic and distinct cropping patterns}

There are some cropping patterns which are extremely location-specific, however, with large area coverage. These are Fallow-Jute-T. Aman (Table 6), Lentil-Vegetables-Vegetables (Table 4) and Mustard-Boro-B. Aman (Table 7). The Fallow-Jute-T. Aman is grown only in Goplaganj sadar upazila (1,200 ha). LentilVegetables-Vegetables is cultivated only in Madhukhali upazila on 1,900 ha of land. Mustard-Boro-B. Aman is limited to two upazilas viz Kalkini (720 ha) and sadar upazila $(1,900)$ in Madaripur district.

\section{Rare cropping patterns}

In the present investigation, 42 cropping patterns have been identified as rare cropping patterns with negligible area coverage and seldom existence (Table 8). These are location specific system and are limited in one or two or in some cases three upazilas of the region. Total area coverage of the 42 patterns is far less than $1 \%$ of NCA. Among these, the highest area was allotted for Fallow-Sesame+B. Aman and Onion-Sesame-T. Aman (200 ha for each). These are recorded in Madhukhali upazila of Faridpur and Kalukhali upazila of Rajbari district. The smallest area was recorded for two cropping patterns whose coverage was five hectares for each (Table 8).

\section{Most dominant cropping pattern}

Boro-Fallow-Fallow was the most dominant cropping pattern in Faridpur region. It covers $24.41 \%$ of NCA in the region and is available in 28 upazilas out of 29 (Table 9). The highest area under this cropping pattern was recorded 23,000 hectares in Kotalipara upazila which represents $19.21 \%$ of the total single Boro area of the region. In respect to individual upazila the highest area is also covered by the Kotalipara upazila and it is $83 \%$ of its NCA for this pattern alone. Saltha, Janjira and Sadarpur upazila had negligible area coverage for this pattern. This pattern is frequent and concurrently experienced by early flash flood in April and cold injury at reproductive stage. Diversified cropping pattern may be resort for the farmer as a coping strategy with flood related risk (Mandal and Bezbaruah, 2013) but scope of diversification is limited due to environmental and climatic condition (FAO, 1988). In the country-wide data compilation it was observed that the single Boro was the $2^{\text {nd }}$ dominant cropping pattern in Bangladesh covering 1.14 million ha (13\% of NCA in the country) with its distribution in 342 upazilas of 59 districts (Nasim et al., 2017).

\section{Second dominant cropping pattern}

The second dominant cropping pattern in Faridpur region is Boro-B. Aman. It belongs to $6.94 \%$ of NCA of the region and spread out over 23 upazilas (Table 10). Muksudpur upazila of Gopalganj district holds the highest area (6,300 ha) under this cropping pattern. It contributes $18.5 \%$ share of the Boro-B. Aman cropping area in the region. Rajoir stands in the second position, however, this upazila of Madaripur district has allocated biggest share $34.09 \%$ surface of its NCA. In the country-wide compilation of data it was observed that Boro-B. Aman was the $7^{\text {th }}$ dominant cropping pattern in Bangladesh covering 1.83 lac ha $(2.14 \%$ of NCA in the country) with its distribution in 113 upazilas of 32 districts (Nasimet al., 2017).

\section{Third dominant cropping pattern}

Wheat-Jute-T. Aman cropping pattern holds the third largest area coverage 33,045 hectares in Faridpur region. This area is an equivalent to $6.73 \%$ of NCA in the region. This pattern Wheat-Jute-T. Aman is distributed over 26 upazilas. Pangsa upazila has an area of 5,200 ha for Wheat-Jute-T. Aman which stands for $15.74 \%$ of the total area under this pattern in the region (Table 11). It also covers the biggest share of upazila NCA (31.71\%) allotted over different upazilas. In the country-wide compilation of data it was observed that Wheat-Jute-T. 
Table 8. Rare cropping patterns covering non-significant area in Faridpur region, 2014-15.

\begin{tabular}{|c|c|c|c|c|c|}
\hline & Cropping pattern & Area (ha) & $\%$ of NCA & Frequency & Upazila \\
\hline 01 & Fallow-Sesame+B. Aman & 200 & 0.04 & 1 & Madhukhali \\
\hline 02 & Onion-Sesame-T. Aman & 200 & 0.04 & 1 & Kalukhali \\
\hline 03 & Vegetab-Vegetab-T. Aman & 160 & 0.03 & 2 & Madhukhali+Gosahirhat \\
\hline 04 & Boro-Aus-T. Aman & 150 & 0.03 & 2 & Goalanda+Bhedarganj \\
\hline 05 & Chickpea-Jute-T. Aman & 150 & 0.03 & 3 & Kalkini+Rajoir+Madaripur \\
\hline 06 & Potato-B. Aman & 150 & 0.03 & 1 & Boalmari \\
\hline 07 & Boro-Sesbania-T. Aman & 120 & 0.03 & 2 & Boalmari+Charbhadrasan \\
\hline 08 & Vegetab-Jute-Vegetab & 120 & 0.03 & 1 & Rajoir \\
\hline 09 & Sunflower-Jute-Fallow & 105 & 0.02 & 2 & Tungipara+Shariatpur \\
\hline 10 & Mungbean-Jute-Fallow & 100 & 0.02 & 3 & Faridpur+Gopalganj+Kalkini \\
\hline 11 & Vegetab-Onion-Aus & 100 & 0.02 & 1 & Madaripur \\
\hline 12 & Wheat-Aus-T. Aman & 100 & 0.02 & 1 & Boalmari \\
\hline 13 & Wheat-Vegetab-Vegetab & 100 & 0.02 & 1 & Baliakandi \\
\hline 14 & Chilli-Jute-T. Aman & 90 & 0.02 & 3 & Bhanga+Saltha+Tungipara \\
\hline 15 & S.Potato-B. Aman & 90 & 0.02 & 1 & Kalkini \\
\hline 16 & Boro-Aus-Blackgram & 80 & 0.02 & 1 & Janjira \\
\hline 17 & Mungbean-Jute-T. Aman & 80 & 0.02 & 3 & Gopalganj+Tungipara+Kalkini \\
\hline 18 & Vegetab-Aus-Fallow & 80 & 0.02 & 1 & Janjira \\
\hline 19 & Mustard-Sesame-T. Aman & 70 & 0.01 & 2 & Faridpur+Rajoir \\
\hline 20 & Potato-Vegetab-T. Aman & 70 & 0.01 & 1 & Baliakandi \\
\hline 21 & Mungbean-B.Aus+B. Aman & 60 & 0.01 & 2 & Faridpur+Tungipara \\
\hline 22 & Maize-Jute-Fallow & 55 & 0.01 & 2 & Faridpur +Shariatpur \\
\hline 23 & Coriander-Fallow-Fallow & 50 & 0.01 & 2 & Charbhadrasan+Janjira \\
\hline 24 & Coriander-Vegetab-Fallow & 50 & 0.01 & 1 & Goalanda \\
\hline 25 & Grasspea-Fallow-Fallow & 50 & 0.01 & 1 & Saltha \\
\hline 26 & Maize-Fallow-Fallow & 45 & 0.01 & 2 & Charbhadrasan+Janjira \\
\hline 27 & Muskmelon-B. Aman & 40 & 0.01 & 1 & Rajoir \\
\hline 28 & Boro-Sesbania-Fallow & 30 & 0.01 & 1 & Charbhadrasan \\
\hline 29 & Grasspea-Sesbania-Fallow & 30 & 0.01 & 1 & Bhedarganj \\
\hline 30 & Lentil-Mungbean-T. Aman & 20 & 0.00 & 1 & Rajoir \\
\hline 31 & Potato-Aus-Fallow & 20 & 0.00 & 1 & Charbhadrasan \\
\hline 32 & Potato-Aus-T. Aman & 20 & 0.00 & 1 & Gosahirhat \\
\hline 33 & Sesame-Fallow-T. Aman & 20 & 0.00 & 1 & Kotalipara \\
\hline 34 & Maize-B. Aman & 10 & 0.00 & 1 & Charbhadrasan \\
\hline 35 & Muskmelon-Fallow-Fallow & 10 & 0.00 & 1 & Baliakandi \\
\hline 36 & Muskmelon-Fallow-T.Amn & 10 & 0.00 & 1 & Madhukhali \\
\hline 37 & S.Potato-Fallow-T. Aman & 10 & 0.00 & 1 & Tungipara \\
\hline 38 & Soybean-Fallow-Fallow & 10 & 0.00 & 1 & Bhedarganj \\
\hline 39 & Soybean-Jute-Fallow & 10 & 0.00 & 1 & Bhedarganj \\
\hline 40 & Wheat-Mungbean-T. Aman & 10 & 0.00 & 1 & Tungipara \\
\hline 41 & Mustard-Mungbean-T.Amn & 5 & 0.00 & 1 & Madhukhali \\
\hline \multirow[t]{2}{*}{42} & Tobacco-Fallow-Fallow & 5 & 0.00 & 1 & Saltha \\
\hline & Total & 2885 & 0.59 & - & \\
\hline
\end{tabular}


Table 9. Distribution of the most dominant Boro-F-F cropping pattern in Faridpur region, 2014-15.

\begin{tabular}{|c|c|c|c|c|}
\hline & Upazila & Area (ha) & $\%$ of upazila NCA & $\%$ of the pattern in region \\
\hline 01 & Kotalipara & 23000 & 83.18 & 19.21 \\
\hline 02 & Gopalganj & 17000 & 58.22 & 14.2 \\
\hline 03 & Kasiani & 11000 & 53.14 & 9.19 \\
\hline 04 & Tungipara & 8300 & 77.93 & 6.93 \\
\hline 05 & Kalkini & 8100 & 40.50 & 6.76 \\
\hline 06 & Muksudpur & 7000 & 30.24 & 5.85 \\
\hline 07 & Naria & 5700 & 44.53 & 4.76 \\
\hline 08 & Shibchar & 5200 & 22.22 & 4.34 \\
\hline 09 & Goshairhat & 4600 & 38.17 & 3.84 \\
\hline 10 & Shariatpur & 4200 & 32.56 & 3.51 \\
\hline 11 & Damudya & 3800 & 55.88 & 3.17 \\
\hline 12 & Rajbari & 3200 & 15.31 & 2.67 \\
\hline 13 & Bhedarganj & 3000 & 16.67 & 2.51 \\
\hline 14 & Rajoir & 2800 & 15.91 & 2.34 \\
\hline 15 & Madaripur & 2600 & 12.18 & 2.17 \\
\hline 16 & Nagarkanda & 1700 & 12.69 & 1.42 \\
\hline 17 & Faridpur & 1500 & 6.41 & 1.25 \\
\hline 18 & Kalukhali & 1500 & 12.40 & 1.25 \\
\hline 19 & Charbhadrasan & 1200 & 14.81 & 1.00 \\
\hline 20 & Bhanga & 850 & 5.99 & 0.71 \\
\hline 21 & Baliakandi & 700 & 4.64 & 0.58 \\
\hline 22 & Pangsa & 700 & 4.27 & 0.58 \\
\hline 23 & Madhukhali & 600 & 4.26 & 0.50 \\
\hline 24 & Alfadanga & 550 & 5.82 & 0.46 \\
\hline 25 & Goalanda & 450 & 4.95 & 0.38 \\
\hline 26 & Saltha & 200 & 1.59 & 0.17 \\
\hline 27 & Janjira & 200 & 1.41 & 0.17 \\
\hline \multirow[t]{2}{*}{28} & Sadarpur & 100 & 0.54 & 0.08 \\
\hline & Faridpur region & 119750 & 24.40 & 100.00 \\
\hline
\end{tabular}

Aman was the $9^{\text {th }}$ dominant cropping pattern in Bangladesh covering 1.47 lac ha $(1.72 \%$ of NCA in the country) with its distribution in 216 upazilas of 43 districts (Nasim et al., 2017).

\section{Fourth dominant cropping pattern}

Fourth dominant cropping pattern Onion-JuteFallow has occupied 25,960 ha representing $5.29 \%$ share of NCA in Faridpur region (Table 12). This pattern is distributed over 23 upazilas where Nagarkanda ranked in top position. This upazila has 5,800 ha area Onion-Jute-Fallow, which is over $43 \%$ of upazila NCA. Boalmari upazila ranks in second position with 5,350 ha area for this pattern; which is also stands in second position in terms of percentage of upazila NCA as well as distribution of the patterns in the region.
Fifth dominant cropping pattern

The fifth dominant cropping pattern of the region is Onion-Jute-T. Aman. It had been covering 24,510 hectares representing 4.99\% share of NCA in Faridpur region (Table 13). This pattern is distributed over 14 upazilas where Saltha ranked in top position. This upazila had 7,000 ha area for Onion-Jute-T. Aman pattern which is $55.56 \%$ of its upazila NCA. This is also the highest area coverage $(28.56 \%)$ in respect of this pattern in the region.

\section{Crop diversity and cropping intensity}

The level of crop diversification largely depends on the geo-climatic or socio-economic conditions and technological development in a region (Bhatia, 1965). Higher number of available crops under cultivation in an 
Table 10. Distribution of the $2^{\text {nd }}$ dominant Boro-B. Aman cropping pattern in Faridpur region, $2014-15$.

\begin{tabular}{|c|c|c|c|c|}
\hline & Upazila & Area (ha) & $\%$ of upazila NCA & $\%$ of the pattern in region \\
\hline 01 & Muksudpur & 6300 & 27.21 & 18.50 \\
\hline 02 & Rajoir & 6000 & 34.09 & 17.62 \\
\hline 03 & Madaripur & 5000 & 23.42 & 14.68 \\
\hline 04 & Bhanga & 2100 & 14.79 & 6.17 \\
\hline 05 & Sadarpur & 2000 & 10.78 & 5.87 \\
\hline 06 & Kasiani & 1500 & 7.25 & 4.40 \\
\hline 07 & Kotalipara & 1300 & 4.70 & 3.82 \\
\hline 08 & Shariatpur & 1300 & 10.08 & 3.82 \\
\hline 09 & Faridpur & 1000 & 4.27 & 2.94 \\
\hline 10 & Rajbari & 1000 & 4.78 & 2.94 \\
\hline 11 & Bhedarganj & 900 & 5.00 & 2.64 \\
\hline 12 & Naria & 900 & 7.03 & 2.64 \\
\hline 13 & Kalkini & 850 & 4.25 & 2.50 \\
\hline 14 & Nagarkanda & 800 & 5.97 & 2.35 \\
\hline 15 & Gopalganj & 800 & 2.74 & 2.35 \\
\hline 16 & Alfadanga & 700 & 7.41 & 2.06 \\
\hline 17 & Damudya & 400 & 5.88 & 1.17 \\
\hline 18 & Goshairhat & 400 & 3.32 & 1.17 \\
\hline 19 & Madhukhali & 280 & 1.99 & 0.82 \\
\hline 20 & Saltha & 200 & 1.59 & 0.59 \\
\hline 21 & Kalukhali & 200 & 1.65 & 0.59 \\
\hline 22 & Tungipara & 80 & 0.75 & 0.23 \\
\hline \multirow[t]{2}{*}{23} & Boalmari & 50 & 0.24 & 0.15 \\
\hline & Faridpur region & 34060 & 6.94 & 100.00 \\
\hline
\end{tabular}

area dictates its higher diversity. Number of cropping patterns is also a gross indicator of crop diversity. A total of 141 cropping patterns were identified in the whole area of Faridpur region under this investigation. The highest number of cropping patterns was identified 44 in Faridpur sadar upazila and that was 42 in Janjira and 40 in Charbhadrasan (Table 14). The lowest number of cropping patterns was identified 12 in Kasiani and Pangsa. The higher number of cropping patterns is generally related to higher level of diversity indices for cropping pattern. The upazilas having lower number of cropping patterns were due to flooding and/ or water logging. The lowest diversity index for cropping pattern was recorded 0.307 in Kotalipara followed by 0.394 in Tungipara upazila. The highest value of diversity index for cropping pattern was found 0.957 in Faridpur sadar that was followed by 0.949 in Janjira upazila. The lowest CDI was reported 0.448 in Kotalipara followed by 0.606 in Tungipara.
The highest value of CDI was observed 0.981 in Faridpur sadar followed by 0.977 in Madhukhali upazila. The range of cropping intensity values was recorded $113-262 \%$. The maximum value was for Saltha upazila of Faridpur district and minimum for Kotalipara upazila of Gopalganj district. As a whole the CDI of Faridpur region was calculated 0.971 and the average cropping intensity at regional level was $197 \%$. In a simultaneous study, the investigators identified 316 cropping patterns for whole Bangladesh; where the CDI value was 0.952 at national level and the national average of cropping intensity was 200\% (Nasim et al., 2017). Diversification of crops helps risk reduction as diversification allows a producer to balance low price in one or two crops with reasonable prices in other (Blade and Slinkard, 2002). The farmers of Kerala diversified their cropping pattern to minimize risk from crop failures and price fluctuations (Mahesh, 1999). 
Table 11. Distribution of the $3^{\text {rd }}$ dominant Wheat-Jute-T. Aman cropping pattern in Faridpur region, 2014-15.

\begin{tabular}{|c|c|c|c|c|}
\hline & Upazila & Area (ha) & $\%$ of upazila NCA & $\%$ of the pattern in region \\
\hline 01 & Pangsa & 5200 & 31.71 & 15.74 \\
\hline 02 & Faridpur & 4000 & 17.09 & 12.1 \\
\hline 03 & Boalmari & 3300 & 16.02 & 9.99 \\
\hline 04 & Sadarpur & 3000 & 16.17 & 9.08 \\
\hline 05 & Bhanga & 2500 & 17.61 & 7.57 \\
\hline 06 & Nagarkanda & 2000 & 14.93 & 6.05 \\
\hline 07 & Rajbari & 2000 & 9.57 & 6.05 \\
\hline 08 & Madhukhli & 1900 & 13.48 & 5.75 \\
\hline 09 & Baliakandi & 1600 & 10.60 & 4.84 \\
\hline 10 & Kalukhali & 1400 & 11.57 & 4.24 \\
\hline 11 & Alfadanga & 900 & 9.52 & 2.72 \\
\hline 12 & Muksudpur & 800 & 3.46 & 2.42 \\
\hline 13 & Shibchar & 700 & 2.99 & 2.12 \\
\hline 14 & Goalanda & 600 & 6.59 & 1.82 \\
\hline 15 & Madaripur & 500 & 2.34 & 1.51 \\
\hline 16 & Saltha & 400 & 3.17 & 1.21 \\
\hline 17 & Naria & 350 & 2.73 & 1.06 \\
\hline 18 & Gopalganj & 300 & 1.03 & 0.91 \\
\hline 19 & Kasiani & 300 & 1.45 & 0.91 \\
\hline 20 & Bhedarganj & 250 & 1.39 & 0.76 \\
\hline 21 & Tungipara & 230 & 2.16 & 0.70 \\
\hline 22 & Damudya & 220 & 3.24 & 0.67 \\
\hline 23 & Goshairhat & 220 & 1.83 & 0.67 \\
\hline 24 & Kalkini & 200 & 1.00 & 0.61 \\
\hline 25 & Shariatpur & 100 & 0.78 & 0.30 \\
\hline \multirow[t]{2}{*}{26} & Janjira & 75 & 0.53 & 0.23 \\
\hline & Faridpur region & 33045 & 6.73 & 100.00 \\
\hline
\end{tabular}

Table 12. Distribution of the $4^{\text {th }}$ dominant Onion-Jute-Fallow cropping pattern in Faridpur region, $2014-15$.

\begin{tabular}{|c|c|c|c|c|}
\hline & Upazila & Area (ha) & $\%$ of upazila NCA & $\%$ of the pattern in region \\
\hline 01 & Nagarkanda & 5800 & 43.28 & 22.34 \\
\hline 02 & Boalmari & 5350 & 25.97 & 20.61 \\
\hline 03 & Saltha & 2300 & 18.25 & 8.86 \\
\hline 04 & Kalukhali & 1800 & 14.88 & 6.93 \\
\hline 05 & Faridpur & 1500 & 6.41 & 5.78 \\
\hline 06 & Baliakandi & 1500 & 9.93 & 5.78 \\
\hline 07 & Sadarpur & 1300 & 7.01 & 5.01 \\
\hline 08 & Janjira & 1080 & 7.61 & 4.16 \\
\hline 09 & Goalanda & 850 & 9.34 & 3.27 \\
\hline 10 & Bhanga & 800 & 5.63 & 3.08 \\
\hline 11 & Shibchar & 800 & 3.42 & 3.08 \\
\hline 12 & Rajbari & 550 & 2.63 & 2.12 \\
\hline 13 & Kasiani & 500 & 2.42 & 1.93 \\
\hline 14 & Alfadanga & 470 & 4.97 & 1.81 \\
\hline 15 & Muksudpur & 400 & 1.73 & 1.54 \\
\hline 16 & Charbhadrasan & 250 & 3.09 & 0.96 \\
\hline 17 & Tungipara & 200 & 1.88 & 0.77 \\
\hline 18 & Kalkini & 120 & 0.60 & 0.46 \\
\hline 19 & Madaripur & 100 & 0.47 & 0.39 \\
\hline 20 & Bhedarganj & 100 & 0.56 & 0.39 \\
\hline 21 & Shariatpur & 70 & 0.54 & 0.27 \\
\hline 22 & Madhukhali & 60 & 0.43 & 0.23 \\
\hline 23 & Rajoir & 60 & 0.34 & 0.23 \\
\hline 24 & Faridpur region & 25960 & 5.29 & 100.00 \\
\hline
\end{tabular}


Table 13. Distribution of the $5^{\text {th }}$ dominant Onion-Jute-T. Aman cropping pattern in Faridpur region, 2014-15.

\begin{tabular}{llccc}
\hline & Upazila & Area (ha) & \% of upazila NCA & \% of the pattern in region \\
\hline 01 & Saltha & 7000 & 55.56 & 28.56 \\
02 & Pangsa & 3400 & 20.73 & 13.87 \\
03 & Baliakandi & 2800 & 18.54 & 11.42 \\
04 & Kalukhali & 2800 & 23.14 & 11.42 \\
05 & Madhukhali & 2000 & 14.18 & 8.16 \\
06 & Shibchar & 1800 & 7.69 & 7.34 \\
07 & Faridpur & 1000 & 4.27 & 4.08 \\
08 & Bhanga & 900 & 6.34 & 3.67 \\
09 & Sadarpur & 900 & 4.85 & 3.67 \\
10 & Rajbari & 600 & 2.87 & 2.45 \\
11 & Nagarkanda & 500 & 3.73 & 2.04 \\
12 & Muksudpur & 400 & 1.73 & 1.63 \\
13 & Naria & 360 & 2.81 & 1.47 \\
14 & Damudya & 50 & 0.74 & 0.20 \\
\hline
\end{tabular}

Table 14. Crop diversity and cropping intensity in Faridpur region, 2014-15.

\begin{tabular}{|c|c|c|c|c|c|c|}
\hline & Upazila & $\begin{array}{l}\text { No. of identified } \\
\text { pattern }\end{array}$ & No. of crop & $\begin{array}{l}\text { Diversity index for } \\
\text { cropping pattern }\end{array}$ & $\begin{array}{l}\text { Crop diversity } \\
\text { index (CDI) }\end{array}$ & C.I. (\%) \\
\hline 01 & Alfadanga & 18 & 15 & 0.917 & 0.957 & 205 \\
\hline 02 & Bhanga & 16 & 16 & 0.887 & 0.947 & 224 \\
\hline 03 & Boalmari & 21 & 19 & 0.861 & 0.948 & 234 \\
\hline 04 & Charbhadrasan & 40 & 22 & 0.942 & 0.970 & 183 \\
\hline 05 & Faridpur sadar & 44 & 25 & 0.957 & 0.981 & 216 \\
\hline 06 & Madhukhali & 39 & 22 & 0.937 & 0.977 & 237 \\
\hline 07 & Nagarkanda & 17 & 14 & 0.779 & 0.901 & 214 \\
\hline 08 & Sadarpur & 21 & 22 & 0.909 & 0.959 & 228 \\
\hline 09 & Saltha & 23 & 16 & 0.649 & 0.850 & 262 \\
\hline 10 & Gopalganj sadar & 25 & 18 & 0.675 & 0.848 & 151 \\
\hline 11 & Kasiani & 12 & 10 & 0.692 & 0.732 & 153 \\
\hline 12 & Kotalipara & 16 & 14 & 0.307 & 0.448 & 113 \\
\hline 13 & Muksudpur & 17 & 15 & 0.810 & 0.912 & 184 \\
\hline 14 & Tungipara & 28 & 22 & 0.394 & 0.606 & 126 \\
\hline 15 & Kalkini & 30 & 19 & 0.822 & 0.935 & 179 \\
\hline 16 & Madaripur sadar & 23 & 17 & 0.883 & 0.952 & 224 \\
\hline 17 & Rajoir & 29 & 21 & 0.837 & 0.922 & 201 \\
\hline 18 & Shibchar & 18 & 14 & 0.908 & 0.966 & 211 \\
\hline 19 & Baliakandi & 24 & 21 & 0.924 & 0.965 & 247 \\
\hline 20 & Goalanda & 22 & 17 & 0.931 & 0.966 & 205 \\
\hline 21 & Kalukhali & 16 & 13 & 0.885 & 0.943 & 231 \\
\hline 22 & Pangsa & 12 & 12 & 0.852 & 0.928 & 244 \\
\hline 23 & Rajbari sadar & 18 & 15 & 0.928 & 0.971 & 229 \\
\hline 24 & Bhedarganj & 33 & 21 & 0.935 & 0.970 & 191 \\
\hline 25 & Damudya & 22 & 17 & 0.689 & 0.871 & 163 \\
\hline 26 & Goshairhat & 22 & 13 & 0.843 & 0.938 & 175 \\
\hline 27 & Naria & 22 & 13 & 0.783 & 0.902 & 156 \\
\hline 28 & Shariatpur sadar & 30 & 22 & 0.851 & 0.930 & 168 \\
\hline 29 & Janjira & 42 & 21 & 0.949 & 0.974 & 199 \\
\hline & Faridpur region & 141 & 34 & 0.918 & 0.971 & 197 \\
\hline
\end{tabular}

170 Mostafizur et al 


\section{CONCLUSION}

Faridpur region holds a wide range of cropping patterns with diversified crops. The intensity of cropping in the region is more or less similar to the national average but the country demands more to cope with its huge population within its limited resources. The less intensified area of the region is under deep water ecosystem which covers a major share of the regional NCA. Single Boro and Boro-B. Aman cropping patterns are the dominant patterns in this ecosystem. Based on the findings of the study, the following recommendations were made.

- Necessary steps need to be taken to increase the productivity of exclusive rice based cropping patterns. As rice is the major component of the food security in context of our country, we need to explore some high yielding rice varieties along with the recommended crop management practices for deep water ecosystem.

- The upazilas having unique or exceptional cropping patterns with large area coverage might be studied in-depth to extrapolate to similar environments.

- Scope might be explored for the establishment of agro-industry on the basis of jute crop.

- Research and development activities can be taken in hand to diversify the single and double cropped area with the inclusion of new crops and crop varieties.

- In the single Boro area suitable vegetables might be grown on floating bed system in wet season.

\section{REFERENCES}

Bhatia, S S. 1965. Patterns of crop concentration and diversification in India, Economic Geography, 41: 40-55.
Blade, S F and A E Slinkard. 2002. New Crop Development: The Canadian Experience. In: Trends in New Crops and New Uses. J Janick and AWhipkey (Editors). ASHS Press, Alexandria.

Chandrasekaran B, K Annadurai and E Somasundaram. 2010. A Textbook of Agronomy, New Delhi, New Age International ( $\mathrm{P}$ ) Limited, 182p.

FAO. 1988. Land Resources Appraisal of Bangladesh for Agricultural Development- Report 2: Agro-ecological regions of Bangladesh. Food and Agriculture Organization of the United Nations, Rome, Italy, $570 \mathrm{p}$.

Hossain, D. 1996. Relative profitability from alternative cropping patterns under irrigated conditions in selected areas of Bogra district. M. S. Ag. Econ. Thesis. Bangladesh Agricultural University, Mymensingh.

Jackson, B R, A Yantasast, C Prechachat, M A Chowdhury and S M H Zaman. 1972. Breeding rice for deep-water areas. Pages 517-528 In: International Rice Research Institute, Rice Breeding, LosBaños, Philippines.

Kshirsagar, K G, S Pandey and M R Bellon. 1997. Farmers' perception, varietal characteristics and technology adoption: the case of rainfed village in eastern India. Discussion paper 5/97. Social Sciences Division, International Rice Research Institute. Los Baňos, Laguna, Philippines.

Mahesh, R. 1999. Causes and consequences of change in cropping pattern: A location specific study. Discussion Paper No. 11, Kerala Research Programme on Local Level Development, Centre for Development Studies, Thiruvananthapura.

Mandal, R and M P Bezbaruah. 2013. Diversification of cropping pattern: its determinants and role in flood affected agriculture of Assam Plains. Indian J. Agric. Econ. 68(2): 169-181.

Muttaleb, M A, S M Shahidullah, M Nasim and A Saha. 2017. Cropping systems and land use in Sylhet region. Bangladesh Rice J. 21(2): 273-288.

Nasim, M, S M Shahidullah, A Saha, M A Muttaleb, T L Aditya, M A Ali and M S Kabir. 2017. Distribution of Crops and Cropping Patterns in Bangladesh. Bangladesh Rice J. 21(2): 1-55.

Shahidullah, S M, M Nasim, M K Quais and A Saha. 2017. Diversity of Cropping Systems in Chittagong Region. Bangladesh Rice J. 21(2): 109-122.

Shriar, A J. 2000. Agricultural intensity and its measurement in frontier regions. Agroforestry Systems. 49(3): 301318. 
Appendix 1. List of cropping patterns in Faridpur region, 2014-15.

\begin{tabular}{|c|c|c|c|c|c|}
\hline & Cropping pattern & Area (ha) & & Cropping pattern & Area (ha) \\
\hline 01 & Boro-Fallow-Fallow & 119750 & 51 & Groundnut- Aus-Fallow & 1150 \\
\hline 02 & Boro-B. Aman & 34060 & 52 & Lentil-Sesame-Fallow & 1125 \\
\hline 03 & Wheat-Jute-T. Aman & 33045 & 53 & Mustard-B. Aman & 990 \\
\hline 04 & Onion-Jute-Fallow & 25960 & 54 & Mustard-B.Aus+B. Aman & 980 \\
\hline 05 & Onion-Jute-T. Aman & 24510 & 55 & Sesame-Aus-Fallow & 950 \\
\hline 06 & Wheat-Jute-Fallow & 23210 & 56 & Pea-Jute-Fallow & 910 \\
\hline 07 & Boro-Fallow-T. Aman & 17685 & 57 & Lentil-Fallow-T. Aman & 830 \\
\hline 08 & Lentil-Jute-Fallow & 15330 & 58 & Chilli-Vegetab-Fallow & 810 \\
\hline 09 & Mustard-Jute-Fallow & 13880 & 59 & Wheat-Fallow-T. Aman & 780 \\
\hline 10 & Lentil-Jute-T. Aman & 13230 & 60 & Grasspea-B.Aus+B. Aman & 770 \\
\hline 11 & Grasspea-Jute-Fallow & 12680 & 61 & Blackgram-Jute-Fallow & 735 \\
\hline 12 & Mustard-Jute-T. Aman & 10580 & 62 & Coriander-Sesame-T. Aman & 700 \\
\hline 13 & Vegetab-Vegetab-Vegetab & 8420 & 63 & Grasspea-Sesame-T. Aman & 700 \\
\hline 14 & Coriander-Jute-Fallow & 6510 & 64 & Boro-Aus-Fallow & 685 \\
\hline 15 & Mustard-Boro-Fallow & 6170 & 65 & Sesame-Fallow-Blackgram & 680 \\
\hline 16 & Garlic-Jute-Fallow & 6020 & 66 & Lentil-Aus-Fallow & 670 \\
\hline 17 & Chilli-B. Aman & 4370 & 67 & Chilli-Fallow-T. Aman & 620 \\
\hline 18 & Vegetab-Vegetab-Fallow & 4255 & 68 & Wheat-Aus-Blackgram & 550 \\
\hline 19 & Grasspea-B. Aman & 4140 & 69 & W.Melon-Fallow-Fallow & 510 \\
\hline 20 & Vegetab-Jute-Fallow & 3820 & 70 & W.Melon-B. Aman & 505 \\
\hline 21 & Garlic-Jute-T. Aman & 3570 & 71 & Fallow-B. Aman & 500 \\
\hline 22 & Coriander-Jute-T. Aman & 3380 & 72 & Groundnut-Fallow-Blackgram & 500 \\
\hline 23 & Lentil-Sesame-T. Aman & 3280 & 73 & Mustard-Fallow-T. Aman & 500 \\
\hline 24 & Onion-Aus-Fallow & 2860 & 74 & Onion-Sesame-Fallow & 500 \\
\hline 25 & Mustard-Boro-B. Aman & 2620 & 75 & S.Potato-Fallow-Fallow & 495 \\
\hline 26 & Grasspea-Jute-T. Aman & 2460 & 76 & Potato-Jute-T. Aman & 485 \\
\hline 27 & Groundnut-B. Aman & 2400 & 77 & Garlic-B. Aman & 480 \\
\hline 28 & Vegetab-Jute-T. Aman & 2290 & 78 & Sesame-Aus-T. Aman & 460 \\
\hline 29 & Wheat-Sesame-T. Aman & 2170 & 79 & Vegetab-Fallow-Fallow & 450 \\
\hline 30 & Lentil-B. Aman & 2130 & 80 & Vegetab-B. Aman & 430 \\
\hline 31 & Mustard-Aus-Fallow & 2090 & 81 & Boro-Jute-T. Aman & 400 \\
\hline 32 & Chilli-Jute-Fallow & 2045 & 82 & Onion-Vegtab-Vegetab & 400 \\
\hline 33 & Lentil-Vegetab-Vegetab & 1910 & 83 & Fallow-Fallow-Blackgram & 370 \\
\hline 34 & Blackcumin-Jute-Fallow & 1780 & 84 & Lentil-Aus-T. Aman & 350 \\
\hline 35 & Potato-Jute-Fallow & 1735 & 85 & Mustard-Sesame+B. Aman & 350 \\
\hline 36 & Pea-B. Aman & 1730 & 86 & Wheat-Ginger/Turmeric & 350 \\
\hline 37 & Onion-B. Aman & 1620 & 87 & Grasspea-Aus-T. Aman & 330 \\
\hline 38 & Mustard-Boro-T. Aman & 1590 & 88 & Mustard-Aus-T. Aman & 320 \\
\hline 39 & Chilli-Aus-Fallow & 1570 & 89 & Groundnut-Fallow-T. Aman & 310 \\
\hline 40 & Grasspea-Fallow-T. Aman & 1510 & 90 & Onion-Sesame+B. Aman & 300 \\
\hline 41 & Wheat-B. Aman & 1500 & 91 & Pea-Fallow-T. Aman & 290 \\
\hline 42 & Groundnut-Fallow-Fallow & 1480 & 92 & Garlic-Aus-Fallow & 280 \\
\hline 43 & Grasspea-Boro-Fallow & 1430 & 93 & Vegetab-Fallow-T. Aman & 280 \\
\hline 44 & Chilli-Fallow-Fallow & 1360 & 94 & Sesame-Jute-T. Aman & 260 \\
\hline 45 & Blackgram-B. Aman & 1300 & 95 & Boro-Vegetab(Float/Norm) & 245 \\
\hline 46 & Boro-Fallow-Blackgram & 1250 & 96 & S.Potato-Jute-Fallow & 230 \\
\hline 47 & Blackcumin-Jute-T. Aman & 1220 & 97 & Wheat-Sesame-Fallow & 230 \\
\hline 48 & Fallow-Jute-T. Aman & 1200 & 98 & Fallow-Sesame-T. Aman & 210 \\
\hline 49 & Wheat-Aus-Fallow & 1200 & 99 & Grasspea-Sesame-Fallow & 210 \\
\hline 50 & Boro-Jute-Fallow & 1150 & $100-141$ & Other 42 patterns (Table 8 ) & 910 \\
\hline
\end{tabular}

